\title{
Antibody Response to Human Immunodeficiency Virus in Homosexual Men \\ Relation of Antibody Specificity, Titer, and Isotype to Clinical Status, Severity of Immunodeficiency, and Disease Progression
}

\author{
J. S. McDougal, M. S. Kennedy, J. K. A. Nicholson, T. J. Spira, H. W. Jaffe, J. E. Kaplan, D. B. Fishbein, P. O'Malley, \\ C. H. Alolsio, C. M. Black, M. Hubbard, and C. B. Reimer \\ Immunology Branch and Immunochemistry Section, Division of Host Factors, and the Epidemiology Branch, Acquired Immunodeficiency \\ Syndrome (AIDS) Program, Center for Infectious Diseases, Centers for Disease Control, Public Health Service, \\ U. S. Department of Health and Human Services, Atlanta, Georgia 30333
}

\begin{abstract}
The titers and isotypes of antibodies to specific proteins of the human immunodeficiency virus were determined by Western blot analysis of sera from 107 homosexual men.

Antibody titers were generally lower in sera from patients with the acquired immunodeficiency syndrome (AIDS) and in sera from men whose condition subsequently progressed to AIDS than in sera from men who had not progressed to AIDS. We found no evidence of isotypic prominence or restriction of the antibody response. In multivariate analysis, lower levels of CD4 helper cells were most highly associated with progression to AIDS. Lower antibody titers to the envelope protein gp110, the core protein p24, and the reverse transeriptase enzyme p51/65 were also predictive of progression to AIDS independent of their association with CD4 cell levels. These data suggest that differences in antibody levels are not simply a consequence of severe immunodeficiency but may be markers for control of infection.
\end{abstract}

\section{Introduction}

The human immunodeficiency virus (HIV) ${ }^{1}$ infects, replicates in, and depletes T cells with the CD4 phenotype (helper T cells) (1). CD4 cells are instrumental in the induction of a variety of immune responses including the $T$ and $B$ cell interactions required for the humoral antibody response to complex antigens (2). Progressive numerical and functional depletion of CD4 cells in HIV infection leads to a poorly responsive immune system that renders the host susceptible to opportunistic infections and malignancies, manifestations of the acquired immunodeficiency syndrome (AIDS). Infection does not preclude an immune response to the virus. For example, infected persons mount and sustain a vigorous antibody response to HIV, which can be of considerable titer. While the presence of antibody to HIV has been a reliable marker for exposure and probable current infection, it is not clear what role, if any, antibody plays in controlling HIV infection. Antibody does have some capacity to inhibit virus replication in vitro (neutralization) (3-6), but disease often

Address reprint requests to Dr. McDougal, Immunology Branch, 1-1202, Centers for Disease Control, Atlanta, GA 30333.

Received for publication 10 November 1986 and in revised form 1 April 1987.

1. Abbreviations used in this paper: $\mathrm{CDC}$, Centers for Disease Control; HIV, human immunodeficiency virus; mAb, monoclonal antibody; PGL, persistent generalized lymphadenopathy.

The Journal of Clinical Investigation, Inc.

Volume 80, August 1987, 316-324 progresses despite the presence of antibody. It has been noted that HIV-infected persons with severe immunodeficiency and AIDS tend to have lower levels of antibody to HIV (7-14). An apparent distortion in specificity of the response has also been noted. Patients with AIDS tend to have prominent reactions with the transmembrane protein gp41 and relatively weak or no responses to the core protein p24, whereas p24 reactivity is a much more prominent feature in persons without clinical symptoms of AIDS (8-12, 14, 15). It has not been determined whether the differences in level or specificity of antibody are characteristics that predispose to the development of more severe disease or are a consequence of the severe immunologic unresponsiveness that characterizes AIDS patients.

In this study, sera from 107 anti-HIV-seropositive homosexual men were tested by Western blot for quantitative antibody levels and qualitative isotypic responses to specific viral proteins. Results were analyzed for their relationship to clinical status, severity of immunodeficiency, and clinical outcome. Changes in antibody titer to specific viral proteins are in part a consequence of immunodeficiency. However, there are strong associations of certain antibody responses with clinical outcome that are independent of severity of immunodeficiency (as measured by CD4 cell levels), which indicates that antibody may have a role in (or is a marker for) control of infection.

\section{Methods}

Study subjects. Anti-HIV-seropositive homosexual or bisexual men were participants in clinical studies of HIV infection conducted by the Centers for Disease Control (CDC) in Atlanta and San Francisco (16, 17). Specimens were collected from late 1982 through 1984. All subjects were examined at the time of specimen collection. From these studies, we identified 25 men whose condition had progressed to AIDS but who had been asymptomatic $(n=7)$ or had had persistent generalized lymphadenopathy (PGL) $(n=18)$ at the time of specimen collection (progressors). Average interval from specimen collection to onset of AIDS was $14 \mathrm{mo}$ (median, $10 \mathrm{mo}$; range, 2 to $38 \mathrm{mo}$ ). The other asymptomatic men $(n=37)$ and men with PGL $(n=20)$ had not had a change in clinical status (nonprogressors), and specimens were collected over the same calendar time. The nonprogressors were selected on the basis of availability of information from a current follow-up examination and adequate specimens to perform the studies envisioned. Average interval from specimen collection to follow-up was 29 mo (median 24 mo; range, 17 to $46 \mathrm{mo})$. Men with AIDS $(n=25)$ fulfilled the CDC case definition for AIDS (18). Although not included in data analysis, specimens from 15 anti-HIV-seronegative homosexual men and specimens from healthy CDC personnel were run in all tests.

HIV antibody. Sodium dodecyl sulfate (SDS)-disrupted HIV (lymphadenopathy-associated virus prototype) was resolved by gradient (3.3-20\%) polyacrylamide gel electrophoresis (PAGE), and electrophoretically transferred to nitrocellulose as described $(3,19)$. Nitrocellulose 
strips were reacted with serial fourfold dilutions of test serum beginning with a 1:100 dilution, and antibody reactions were detected with a polyvalent peroxidase-conjugated anti-human immunoglobulin (Ig) reagent as described $(3,19)$. Reactions were scored without knowledge of the serum source. Virus load and reagent concentrations were predetermined for optimal detection. By reference to a common standard, the conditions we used resulted in the following titers with the CDC anti-human T lymphotropic virus-III-positive reference serum (CDC catalogue VS2151): p17, 1:25,600; p24, 1:1,638,400; p31, 1:1,638,400; p39, 1: 102,400; gp41, 1:102,400; p51, 1:1,638,400; p55, 1:1,638,400; p65, 1: 1,638,400; and gp1 10, 1:25,600.

To determine the isotype distribution of HIV antibody, nitrocellulose strips were incubated overnight with a single dilution of test serum (1: 100 ), washed, incubated with a combination of monoclonal antibodies (mAbs) specific for the isotype for $4 \mathrm{~h}$, washed, and incubated with a 1: 2,000 dilution of peroxidase-conjugated goat anti-mouse Ig reagent for $2 \mathrm{~h}$ (the latter reagent was nonreactive with human Ig and was a gift from Dr. V. Tsang, CDC). Approximately twice as much antigen as normally would be used with the polyvalent anti-Ig reagent was loaded on the gels to increase antigen display and lessen the chance of effective competition for reaction by other isotypes. We used pools of the following monoclonal anti-isotype reagents: for IgG1, HP6001 and HP6069; for IgG2, HP6002 and HP6014; for IgG3, HP6047 and HP6050; for IgG4, HP6023, HP6024, and HP6025; for IgA, HP6104 and HP6123; for IgM, HP6081, HP6082, HP6083, and HP6084. Whenever possible, anti-isotype combinations were selected to react with at least two epitopes of the respective isotype. Validation of the specificity of the anti-human IgG isotype reagents has been described $(20,21)$. The IgA and IgM isotypespecific mAbs were evaluated in a similar manner. Each was tested by quantitative immunofluorometric assay $(20,21)$ in serial dilutions $\left(10^{-2}\right.$ $\left.10^{-5}\right)$ with the following solid-phase antigens $(0.9 \mu \mathrm{g}$ per assay): at least 12 IgM paraproteins, 12 IgA paraproteins (IgA1 and IgA2), 50 IgG paraproteins representative of the four IgG subclasses, $2 \mathrm{IgE}$ paraproteins, polyclonal IgG, IgA, and IgM, secretory IgA, and kappa and lambda Bence-Jones proteins. Each anti-IgA and anti-IgM mAb reacted only with their respective isotypes. These mAbs have also been successfully used as solid-phase reagents for detecting and quantitating fluid-phase isotype in serum and reactions are not perturbed or inhibited by varying the concentration of IgG. When reacted with normal human serum that had been subjected to gradient SDS-PAGE (under nonreducing conditions) and transblotted to nitrocellulose (19), all the mAbs reacted only with components whose molecular weights were appropriate for the respective isotypes. In this study, each $m A b$ was used in a 1:300 final concentration, and each combination reacted with $15-500 \mathrm{ng}$ of isotype when the purified isotypes were applied to nitrocellulose. Under the conditions of serum exposure in this assay ( $3 \mathrm{ml}$ of a 1:100 dilution), this corresponds to a concentration of $0.5-11 \mu \mathrm{g} / \mathrm{ml}$ of isotypic antibody assuming that antigen display and time of incubation were sufficient for near complete binding and that antibody is of reasonable affinity so that loss with washing was minimal.

Tetanus toxoid antibody. One-tenth milliliter of a solution of tetanus toxoid (lot LP501P; Massachusetts Department of Health, Boston, MA) diluted 1:800 in phosphate-buffered saline, pH 8.0 (PBS) was added to wells of microtiter plates (Immulon plates: Dynatech Laboratories, Inc., Alexandria, VA). After $4 \mathrm{~h}$ at room temperature, the wells were washed four times with PBS containing 0.05\% vol/vol Tween-20 (Sigma Chemical Co., St. Louis, MO). Serial twofold dilutions of serum starting with a 1 : 100 dilution were added $(0.1 \mathrm{ml})$, and plates were incubated overnight at $4^{\circ} \mathrm{C}$. After four washes with PBS containing $0.05 \%$ vol/vol Tween$20,0.1 \mathrm{ml}$ of a 1:2,000 dilution of the polyvalent peroxidase-conjugated anti-human IgG reagent described above was added. After $2 \mathrm{~h}$, the wells were washed four times, and $0.2 \mathrm{ml}$ of a solution containing $0.1 \mathrm{mg} / \mathrm{ml}$ o-phenylenediamine and $0.006 \% \mathrm{H}_{2} \mathrm{O}_{2}$ was added. Color reactions developed over $30 \mathrm{~min}$ and were stopped by the addition of $0.05 \mathrm{ml} 8 \mathrm{~N}$ $\mathrm{H}_{2} \mathrm{SO}_{4}$. The optical density at $490 \mathrm{~nm}$ was read with an automated enzyme-linked immunosorbent assay (ELISA) plate reader (Dynatech Laboratories, Inc.). We arbitrarily designated the endpoint titer as the highest dilution that registered an $\mathrm{OD}_{490}>0.300$. Maximum $\mathrm{OD}_{490}$ values were $0.700-0.800$, and reagent or serum controls registered $O_{490}$ values $<0.050$.

Lymphocyte studies. Total T cells (CD3 cells), T helper cells (CD4 cells), and $\mathrm{T}$ suppressor/cytotoxic cells (CD8 cells) were identified by indirect immunofluorescence with OKT3, OKT4A, and OKT8 mAbs, respectively (Ortho Immunodiagnostics, Raritan, NJ), with a fluorescence-activated cell sorter (FACS-IV; Becton-Dickinson \& Co., Sunnyvale, CA) as described (22). Absolute numbers of cells in each subset were calculated as the proportion of cells positive with OKT3, OKT4A, or OKT8 multiplied by the absolute lymphocyte count.

Statistics. Geometric conversion of titer data used the formula: $\log _{2}$ $\left(\right.$ titer $\left.^{-1} / 100\right)+1$ (e.g., titers of 1:100, 1:200, 1:400, etc. transform to 1 , 2,3 , etc.). Undetectable titers $(<1: 100)$ were assigned a value of zero. The Wilcoxon rank sum test was used for comparison of continuous data between groups, and the Fisher's exact test (two-tailed) was used for comparisons of dichotomous data between groups (23). Associations between continuous variables were tested by the Spearman rank correlation method (23). Logistic stepwise regression was used to examine the relation of several "independent" variables (either dichotomous or continuous) to a dichotomous "dependent" variable (progression or nonprogression to AIDS) (23). In the regression analysis, subjects with any missing data are necessarily excluded. Serologic and CD4/CD8 ratio data were complete in all subjects; however, absolute lymphocyte count data (and therefore CD3 cell, CD4 cell, and CD8 cell count) were missing for four men.

\section{Results}

Antibody titers. Serial dilutions of sera were reacted with specific viral proteins in immunoblot, and antibody was detected with a polyvalent anti-Ig reagent (Fig. 1). The banding pattern expected from extracellular virus was obtained. All sera reacted with p24, and 97\% reacted with p17, the two major gag-encoded core proteins $(24,25)$. The $\mathrm{p} 55$ polyprotein, a precursor for $\mathrm{p} 17$ and p24, which is found to some extent in extracellular virus, was also highly reactive with sera (84\%). All sera were reactive with gp41, the transmembrane protein (26). The p51/p65 doublet share antigenicity and represent the pol-encoded reverse transcriptase enzyme (27). Serologic reactions to one or both of these proteins were found in $99 \%$ of sera, reactions were $97 \%$ concordant, and titers were highly correlated $(r=0.88, P=0.0001)$. The p31 antigen is also thought to be encoded by the pol-region and may represent the endonuclease enzyme (28). Reactions to p31 were found in $94 \%$ of sera. Most (84\%) sera had antibody to $\mathrm{gp} 110$, the envelope glycoprotein $(25,29,30)$. Antibody to this protein has been reported to occur in nearly $100 \%$ of HIVinfected persons in radioimmunoprecipitation assays of lysates from HIV-infected cells $(30,31)$. Our immunoblot results with purified extracellular virus approximate this, and the differences in percentage positive may reflect differences in sensitivity of the two techniques, particularly with respect to preservation or enrichment of $\mathrm{gp} 110$ in the two types of antigen preparations $(25,29-31)$. Alternatively, patient selection may account for the differences. (All our anti-gp1 10 negative sera were from patients with AIDS or whose condition progressed to AIDS.) Antibody responses to p14 and p39 were found in 21 and $81 \%$ of sera, respectively. The genetic origin and function of these two proteins are unknown. The tat gene product is reported to have a molecular weight of 14,000 and is antigenic; however, it is not clear whether this protein is packaged in extracellular virus (32). In the comparisons that follow, we analyzed but do not report antibody responses to these two proteins. There were no unique associations of antibody response or titer to p14 or p39 with 


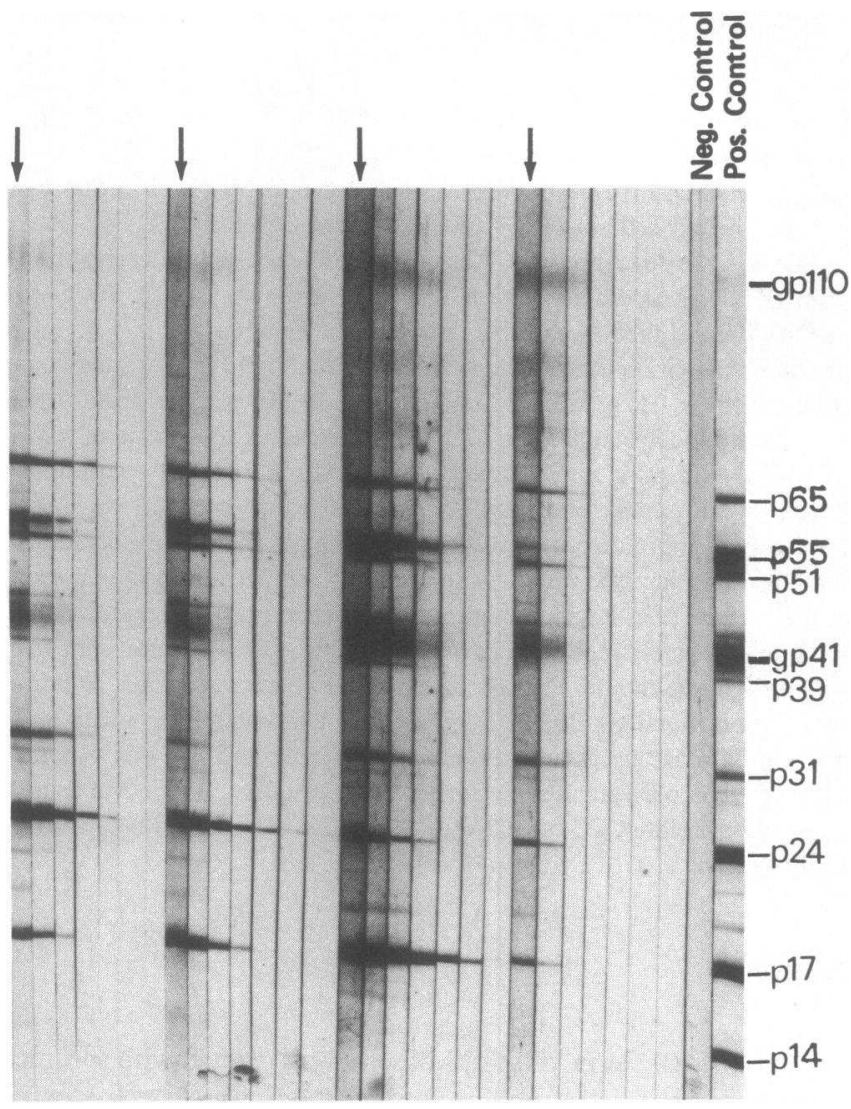

Figure 1. Titration of anti-HIV sera by Western blot. Sera were reacted with nitrocellulose strips containing electrophoretically resolved HIV proteins, and antibody was detected with a polyvalent anti-HIV reagent. Titrations of four sera are shown starting with a 1:100 dilution (arrows). Subsequent fourfold dilutions run left to right.

clinical status or progression that were not also found with other proteins.

A summary of immunoblot titers is presented in Table I, and antibody titers to selected virus proteins are presented graphically in Fig. 2. Antibody titers to all viral proteins except gp41 were significantly lower in AIDS patients than in asymptomatic men or men with PGL. The last two groups did not differ significantly with respect to antibody titers to any antigen. In a correlation matrix, all titers were correlated with each other ( $r=0.21-0.88, P=0.0289-0.0001)$. IgG levels and tetanus toxoid antibody titers were not significantly different between any of the groups.

We pooled data on asymptomatic homosexual men who subsequently developed AIDS (progressors) with data on progressors who had PGL at the time of specimen collection (Table I, Fig. 2). These data were compared with pooled data on asymptomatic men and men with PGL who had not yet progressed to AIDS (nonprogressors). This seemed justified because titers were not significantly different between progressors who were asymptomatic and progressors who had PGL, nor, as mentioned, were titers different between PGL and asymptomatic men who had not developed AIDS (Table I). Without exception, all significant differences in titers between progressors and nonprogressors using pooled data were also significant in separate analyses of the PGL and asymptomatic cohorts, though the $P$ value tended to be higher because of the smaller sample size.
For isotype data (see below), significant differences in frequency of isotypic reactions using pooled data were also found in the asymptomatic cohort but not in the PGL cohort, though the magnitudes of the differences were similar.

Titers of progressors were more similar to those of AIDS patients than to those of their respective PGL and asymptomatic cohorts (Table I, Fig. 2). Progressors had significantly lower antibody titers to p24, p51/65, and gp1 10 than nonprogressors. Titers to p17 and p31 were lower in progressors but not significantly different from those of nonprogressors; and gp41 titers, IgG levels, and tetanus toxoid antibody titers were similar in progressors, nonprogressors, and AIDS patients.

For this study, we report data from the earliest date for which clinical data, serum, and lymphocytes were all available from each man. We have performed titrations on serum specimens drawn 6-24 mo after the specimens reported here from 12 progressors and 8 nonprogressors. We could discern no trends in titers in either group. For instance, all the titers that distinguished progressors from nonprogressors (Table I) were the same or within one dilution of each other in 13 of 20 sequential serum pairs. When titers to individual proteins are tabulated separately in the 20 paired sera, 15 p24 titers, 19 gp41 titers, 17 p51/65 titers, and $17 \mathrm{gp} 110$ titers were the same or within one dilution of each other. The remainder were divided, roughly equally, between rises and falls in titers. In progressors, we have tested four sets of specimens drawn 12-24 mo before the specimens reported here. One progressor had previously had higher titers (two or more dilutions) of antibody to p24 and gp110. The other three were essentially unchanged (within one dilution).

Isotypes of HIV antibody. HIV antibody of defined isotype was detected using isotype-specific mAbs (Fig. 3). We did not titrate or otherwise quantitate isotypic antibodies for several reasons. An ideal quantitative assay would require separation of the isotype from serum before testing so that competition from other isotypes could not be a factor in the assay readout. Second, many sera had levels below the threshold of detection (or had effectively competing isotypes). We felt that titration of those sera with levels at or above the threshold of detection would add little to simply comparing the relative frequencies of sera above/below the threshold of detection. Third, sera and reagents were limited.

The assay is qualitative and detects the functional capacity of each isotypic antibody population to react in the presence of other isotypes in whole serum. Results in Table II are presented as the percentage of sera with detectable isotypic antibody to any viral protein. We also analyzed the frequency of isotypic responses to individual viral proteins, and the statistically significant differences that were found are summarized in Table III. Reactions with gp110 are not reported because they were absent or weak in the isotype assay and could not be reliably or reproducibly scored.

Nearly all sera had IgG1 and IgG2 antibody (Table II). There was no apparent bias of the IgG1 or IgG2 reactions toward any particular viral antigen(s). AIDS patients were less likely than PGL or asymptomatic men to have demonstrable IgG1 and IgG2 antibody to gag-encoded core proteins (p17, p24, and p55)(Table III). Progressors were less likely than nonprogressors to have IgG1 or IgG2 responses to p24 and p55 (Table III) and less likely to have an IgG2 response to any viral protein (Table II).

IgG3 responses were detected less frequently than any other isotype examined (Table II). IgG3 responses that were detected 
Table I. Antibody Titers and IgG Levels in Homosexual Men

\begin{tabular}{|c|c|c|c|c|c|c|c|c|c|c|}
\hline \multicolumn{2}{|l|}{ Group* } & HIV p17 & HIV p24 & HIV p31 & HIV gp4l & HIV p51 & HIV p65 & HIV gp1 10 & $\begin{array}{l}\text { Tetanus } \\
\text { toxoid }\end{array}$ & IgG \\
\hline & & & & & & & & & & $m g / d l$ \\
\hline \multirow{3}{*}{$\begin{array}{l}\text { AIDS } \\
\qquad(n=25)\end{array}$} & Geometric mean ${ }^{\ddagger}$ & 778 & 3,676 & 800 & 3,112 & 1,600 & 2,111 & 894 & 1,364 & 1,677 \\
\hline & $\mathrm{SD}^{\S}$ & $\times / \div 12.1$ & $\times / \div 8.6$ & $\times / \div 4.4$ & $\times / \div 3.3$ & $\times / \div 13.6$ & $\times / \div 12.5$ & $\times / \div 7.9$ & $\times / \div 1.5$ & $\times / \div 1.5$ \\
\hline & Median & 400 & 1,600 & 1,600 & 1,600 & 1,600 & 1,600 & 1,600 & 1,600 & 1,547 \\
\hline \multirow{3}{*}{$\begin{array}{l}\text { PGL } \\
\qquad(n=20)\end{array}$} & Geometric mean & 11,143 & 67,559 & 6,859 & 4,850 & 33,779 & 54,875 & 2,425 & 2,216 & 1,865 \\
\hline & SD & $X / \div 10.1$ & $\times / \div 9.1$ & $\times / \div 13.5$ & $\times / \div 4.3$ & $\times / \div 8.5$ & $\times / \div 8.5$ & $\times / \div 4.2$ & $\times / \div 1.7$ & $\times / \div 1.6$ \\
\hline & Median & 6,400 & 102,400 & 6,400 & 6,400 & 25,600 & 25,600 & 6,400 & 1,600 & 1,853 \\
\hline \multirow{3}{*}{$\begin{array}{l}\text { Asymptomatic } \\
\quad(n=37)\end{array}$} & Geometric mean & 7,003 & 48,100 & 5,930 & 10,043 & 24,728 & 56,028 & 3,027 & 1,392 & 1,442 \\
\hline & SD & $\times / \div 11.8$ & $\times / \div 11.4$ & $\times / \div 6.3$ & $\times / \div 6.7$ & $\times / \div 12.4$ & $\times / \div 5.2$ & $\times / \div 7.8$ & $\times / \div 1.2$ & $\times / \div 1.5$ \\
\hline & Median & 6,400 & 25,600 & 6,400 & 6,400 & 25,600 & 102,400 & 6,400 & 1,600 & 1,505 \\
\hline \multirow{3}{*}{$\begin{array}{l}\text { Progressor } \\
\quad(n=25)\end{array}$} & Geometric mean & 4,106 & 7,558 & 3,478 & 6,400 & 3,478 & 6,225 & 217 & 1,255 & 1,713 \\
\hline & SD & $\times / \div 7.0$ & $\times / \div 6.9$ & $\times / \div 9.3$ & $\times / \div 4.2$ & $\times / \div 12.5$ & $\times / \div 12.0$ & $\times / \div 7.2$ & $\times / \div 1.9$ & $\times / \div 1.4$ \\
\hline & Median & 1,600 & 6,400 & 6,400 & 6,400 & 1,600 & 6,400 & $<100$ & 1,600 & 1,862 \\
\hline \multirow{3}{*}{$\begin{array}{l}\text { Nonprogressor } \\
\quad(n=57)\end{array}$} & Geometric mean & 8,214 & 54,119 & 6,225 & 7,771 & 27,628 & 55,641 & 2,805 & 1,634 & 1,581 \\
\hline & SD & $\times / \div 11.0$ & $\times / \div 10.4$ & $\times / \div 8.3$ & $\times / \div 6.0$ & $\times / \div 10.8$ & $\times / \div 6.1$ & $\times / \div 6.4$ & $\times / \div 1.4$ & $\times / \div 1.7$ \\
\hline & Median & 6,400 & 102,400 & 6,400 & 6,400 & 25,600 & 102,400 & 6,400 & 1,600 & 1,547 \\
\hline \multicolumn{11}{|c|}{ Statistics" ( $P$ value) } \\
\hline \multicolumn{2}{|c|}{ AIDS vs. PGL } & 0.0002 & 0.0002 & 0.0036 & $\mathbf{N S}^{\mathbf{1}}$ & 0.0003 & 0.0001 & 0.048 & NS & NS \\
\hline \multicolumn{2}{|c|}{ AIDS vs. asymptomatic } & 0.0010 & 0.0001 & 0.0001 & NS & 0.0002 & $<0.0001$ & 0.0310 & NS & NS \\
\hline \multicolumn{2}{|c|}{ PGL vs. asymptomatic } & NS & NS & NS & NS & NS & NS & NS & NS & NS \\
\hline \multicolumn{2}{|c|}{ Progressor vs. nonprogressor } & NS & 0.0004 & NS & NS & 0.0007 & 0.0002 & $<0.0001$ & NS & NS \\
\hline
\end{tabular}

* PGL and asymptomatic groups have had a stable clinical course, and their data were pooled (nonprogressors) for comparison with PGL and asymptomatic persons who subsequent to testing developed AIDS (progressors). " ${ }^{\ddagger}$ Anti- $\log _{2}$ of the average of $\log _{2}$-transformed titers. ${ }^{8}$ Standard deviation (for the \pm 2 SD range, take the mean and multiply/divide by the anti- $\log _{2}$ of $2 \times \log _{2}$ SD). "Wilcoxon rank sum test. 'NS, $P>0.05$.

were largely confined to the core proteins, p17, p25, and p55. One serum sample reacted with p51/65, and none reacted with p31 or gp41. An IgG3 response was never detected in an AIDS serum sample, a frequency significantly lower than that of PGL or asymptomatic men (Tables II and III). Progressors had an intermediate frequency of IgG3 responses that was not significantly different from the frequency in nonprogressors.

IgA and IgM response rates did not distinguish any of the clinical groups. They tended to be more frequent in men with PGL than in the other groups and, like the IgG3 response, were directed mainly against core proteins p17, p24, and p55. IgA responses were rarely detected to p31 (four sera), gp41 (one serum) or p51/65 (six sera). Similarly, infrequent IgM responses were found to p51/65 (seven sera), and no IgM responses to p31 or gp41 were found. Men who had IgA or IgM antibody did not differ from those who did not with respect to frequency of other isotype responses, titer data, IgG levels, or lymphocyte data.

Multivariate and correlation analysis. We entered antigenspecific titer data, antigen-specific antibody isotype data, IgG level, tetanus toxoid antibody titer data, lymphocyte count, CD3 cell count, CD4 cell count, CD8 cell count, and CD4/CD8 ratio data into a logistic regression model as independent variables. Progression/nonprogression to AIDS was the dependent variable, and complete data were available on 78 progressor and nonprogressor subjects. The strongest association with (or predictor of) progression was lower numbers of CD4 cells $(F=27.8, P$ $<0.0001$ ). All the other lymphocyte data except $\mathrm{CD} 8$ cell count were also associated with progression: lower absolute lymphocyte count $((F=9.4, P=0.0030)$, lower $C D 3$ cell count $(F=12.0$, $P=0.0009)$, and lower CD4/CD8 ratio $(F=17.6, P=0.0001)$. However, the second strongest association was with lower antibody titer to gp1 $10(F=27.5, P<0.0001)$. All the associations of antibody responses that distinguished progressors from nonprogressors that we found in univariate analysis (Tables I-III) were also found in the initial logistic regression analysis $(F=4.0$ $19.3, P=0.0485$ to $<0.0001$ ). IgG levels and tetanus toxoid antibody titers were not associated with progression.

When the analysis was corrected for CD4 cell counts, data from lymphocyte, CD3 cell, and CD4/CD8 determinations did not retain a significant independent association with progression. Antibody titer to gp110, however, retained an association independent of CD4 cell levels $(F=19.7, P<0.0001)$, as did antibody titers to p24 $(F=7.0, P=0.0100), \mathrm{p} 51(F=8.7, P$ $=0.0042)$, and p65 $(F=10.4, P=0.0019)$. When the analysis was corrected for CD4 cell number and gp1 10 titer, the p24, p51, and p65 titer associations were retained $(F=5.7-6.7, P$ $=0.0192-0.0116)$. At the next step in the regression (correction for CD4 cell number, gp1 10 titer, and p65 titer), no independent associations with progression were retained.

In addition to stepwise regression where the most highly associated variables are sequentially corrected for, we "forced" the regression equation to determine whether CD4 cell count and titers to gp110, p24, p51, and p65 were associated with progression independent of each other. The association of CD4 cell 

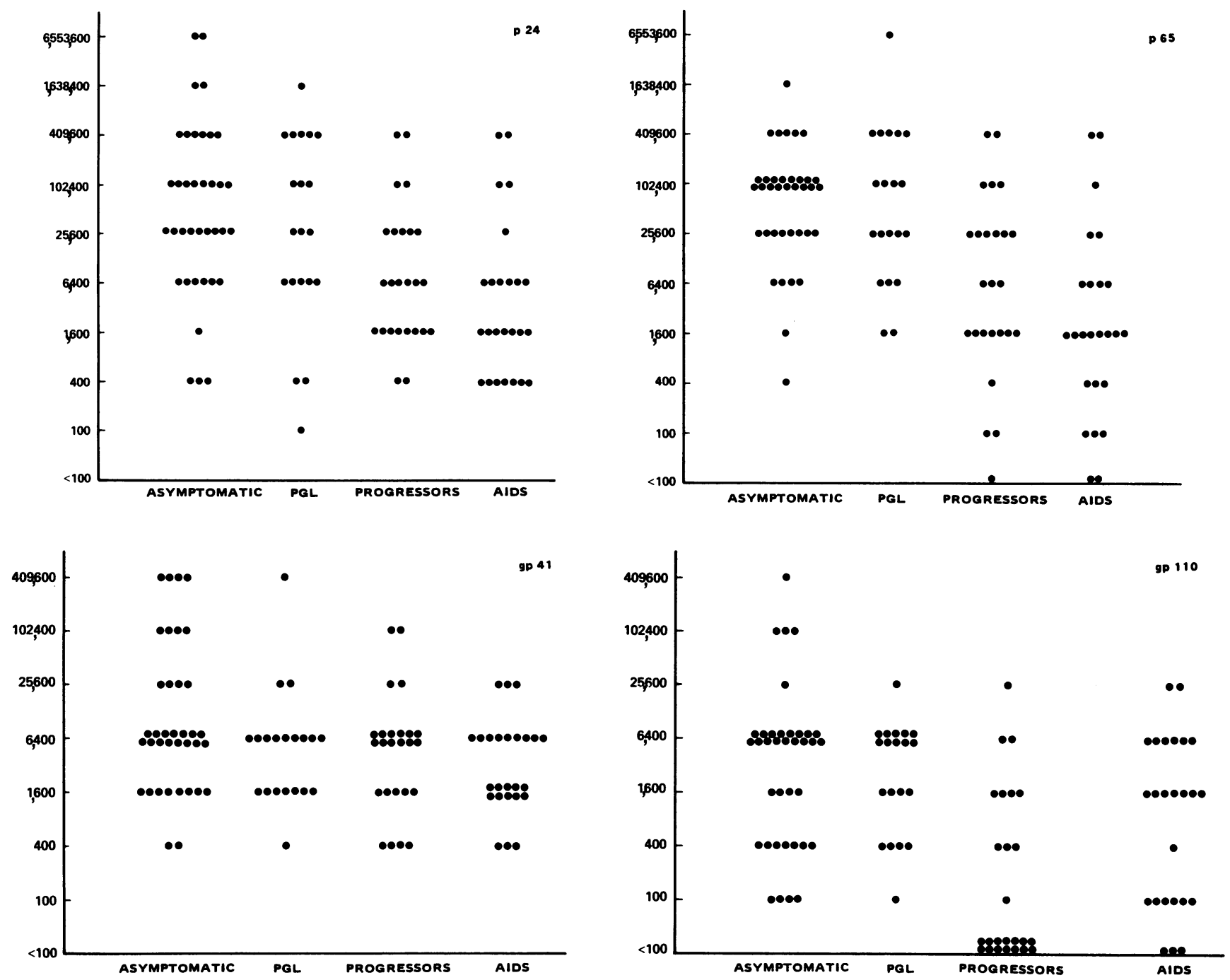

Figure 2. Distribution of antibody titers to HIV proteins in HIV-exposed homosexual men. Antibody titers to p24, p41, p65, and gp110 are shown for asymptomatic men and men with PGL who had a stable clinical course; for progressors, asymptomatic, and PGL men who subsequent to specimen collection developed AIDS; and for men with AIDS.

count with progression was retained if the analysis was first corrected for titer data. Similarly, gp1 10 titer was associated with progression even when first corrected for CD4 cell, p24, p51, or p65 data. The p24, p51, and p65 data, though associated with progression independent of CD4 cell and gp1 10 titer data, were not associated with progression independent of each other.

When the entire data set was pooled $(n=103)$, positive correlations were found between CD4 cell levels and antibody titers to all proteins: $r=0.35-0.45(P=0.0003-0.0001)$ for $\mathrm{p} 17$, p24, p31, p51, p55, and p65 titers; $r=0.27(P=0.0063)$ for gp1 10 titer; and $r=0.22(P=0.0263)$ for gp41 titer. However, when correlation analyses were confined to data from each group, no significant correlations of CD4 cell levels with titer were found.

In progressors, there was a positive correlation of duration from specimen collection to onset of AIDS with gp1 10 titers $(r$ $=0.53, P=0.0083)$ and with CD4 cell levels $(r=0.52, P$ $=0.0093$ ), but not with p24, p51, or p65 titers. In men with PGL, there were no correlations between titer data or CD4 cell levels and duration of lymphadenopathy. In those men in whom approximate seroconversion date was known ( $\pm 6 \mathrm{mo}, n=21)$, there were no correlations between duration of seropositivity and titer data or CD4 cell levels. Note that in the larger clinical studies from which these men were drawn, weak correlations between CD4 cell levels and duration of lymphadenopathy or duration of seropositivity have been found (Spira, T. J., personal communication [17]).

\section{Discussion}

Antibody titers to most viral proteins are lower in AIDS patients and in those whose conditions progress to AIDS than in HIVexposed persons who have a relatively stable clinical course ( $\mathrm{Ta}$ ble I, Fig. 2). Antibody titers to gp41 are an exception in that they are well preserved and similar in AIDS and HIV-exposed persons who do and do not eventually have AIDS. In more limited studies where results were based on the qualitative intensity of banding patterns, others have suggested that antibody to the gag-encoded core protein p24 is often absent or reduced in AIDS patients, while antibody to the env-encoded transmem- 


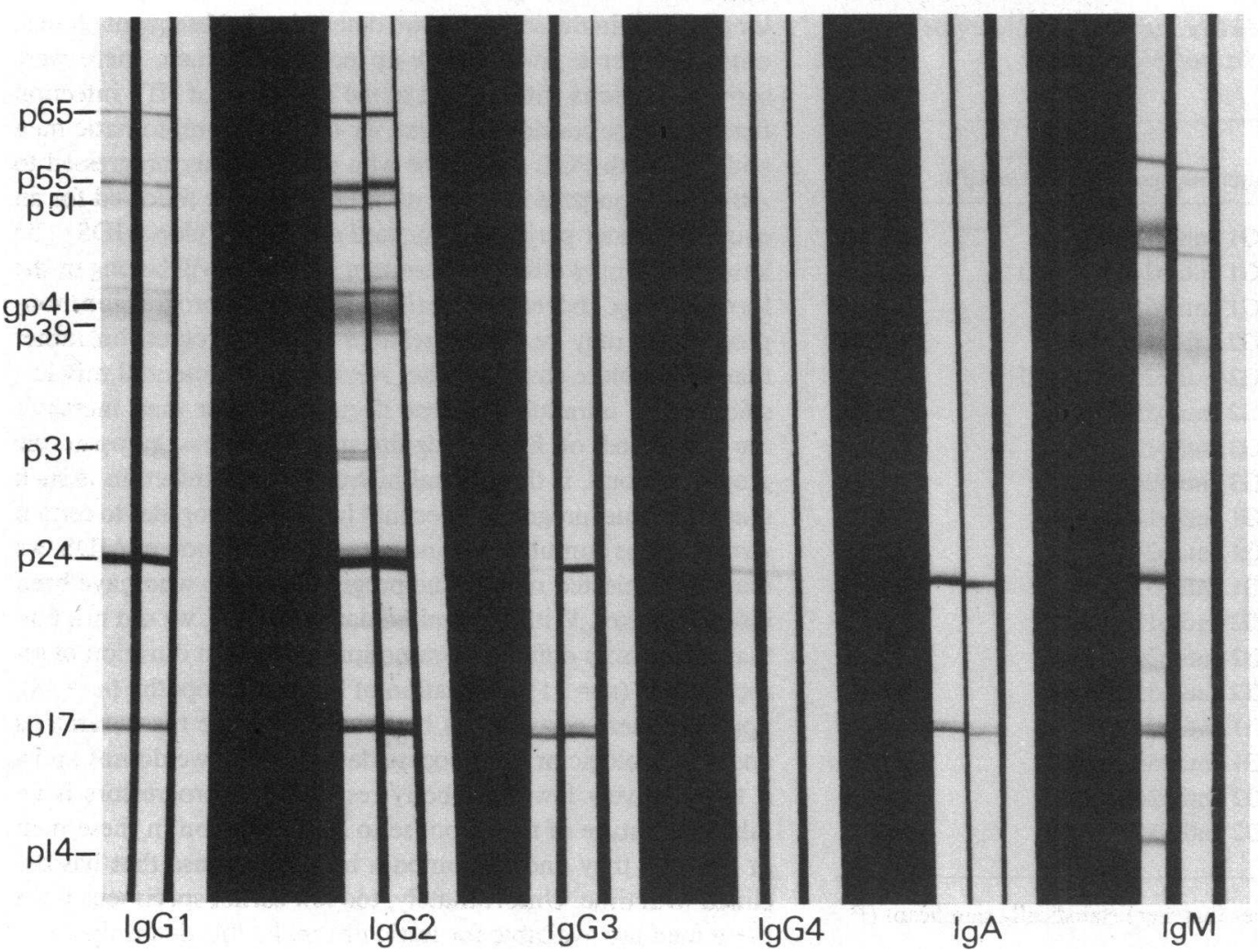

Figure 3. Detection of isotypic HIV antibody. HIV antibody reactions with immunoblots were detected with mAbs specific for IgA, IgM, and the IgG subclasses as indicated. The different sets of triplet strips are not from the same run. Therefore, migration of bands may not precisely align between the sets. Strip on the right in each set is the negative serum control. brane protein $g p 41$ is preserved $(8-12,14,15)$. From these data, it was not clear whether either of these response patterns was also found with responses to other proteins or was unique to the particular protein. Our data indicate that loss of titer to p24 is not unique but is part of a generalized loss of titer to viral proteins. However, the preservation of titer to gp41 is unique. It is not found with other proteins, including the other env-encoded protein gp110. Our data also indicate that these changes are quantitative and not absolute, since we detected some antibody to p24 and gp41 in all sera.

An isotypic dissection of the antibody response to HIV was of interest for two reasons. The determinants of isotypic diversity in the humoral response to specific antigen are complex but generally reflect the maturation state of the response, which in turn is determined by the $\mathrm{T}$-dependent or $\mathrm{T}$-independent nature of the antigen, the adequacy of $T$ cell help, and the route, dose,

Table II. Isotype of HIV Antibodies in Homosexual Men

\begin{tabular}{|c|c|c|c|c|c|c|c|}
\hline \multirow[b]{2}{*}{ Group } & \multirow[b]{2}{*}{$n$} & \multicolumn{6}{|c|}{ \% Positive* } \\
\hline & & IgG1 & IgG2 & IgG3 & IgG4 & IgA & IgM \\
\hline AIDS & 25 & 92 & 88 & 0 & 42 & 84 & 38 \\
\hline PGL & 20 & 100 & 100 & 45 & 63 & 90 & 60 \\
\hline Asymptomatic & 37 & 100 & 100 & 41 & 64 & 68 & 38 \\
\hline Progressors & 25 & 90 & 88 & 28 & 40 & 78 & 44 \\
\hline Nonprogressors & 57 & 100 & 100 & 42 & 64 & 76 & 46 \\
\hline \multicolumn{8}{|c|}{ Statistics $^{\ddagger}(P$ value $)$} \\
\hline \multicolumn{2}{|c|}{ AIDS vs. PGL } & NS & NS & $<0.001$ & NS & NS & NS \\
\hline \multicolumn{2}{|c|}{ AIDS vs. asymptomatic } & NS & NS & $<0.001$ & NS & NS & NS \\
\hline \multicolumn{2}{|c|}{ PGL vs. asymptomatic } & NS & NS & NS & NS & NS & NS \\
\hline \multicolumn{2}{|c|}{ Progressors vs. nonprogressors } & NS & 0.002 & NS & NS & NS & NS \\
\hline
\end{tabular}

\footnotetext{
* Percentage of sera having antibodies of the indicated isotype that are reactive with any viral protein. ${ }^{\ddagger}$ Fisher's exact test (two tailed). ${ }^{8}$ NS, Not significant $(P>0.05)$.
} 
Table III. Summary of Statistically Significant Differences in Frequency of Antigen-specific Isotypic Antibody to HIV in Homosexual Men*

\begin{tabular}{llll}
\hline $\begin{array}{l}\text { Groups compared } \\
\text { (group 1/group 2) }\end{array}$ & Isotypic response & $\begin{array}{l}\text { \% Positive } \\
\text { (group 1/group 2) }\end{array}$ & $P$ value \\
\hline AIDS/PGL & IgG1 anti-p17 & $36 / 70$ & 0.036 \\
AIDS/PGL & IgG1 anti-p24 & $72 / 100$ & 0.012 \\
AIDS/PGL & IgG1 anti-p55 & $24 / 65$ & 0.008 \\
AIDS/PGL & IgG2 anti-p17 & $36 / 75$ & 0.016 \\
AIDS/PGL & IgG2 anti-p24 & $68 / 100$ & 0.006 \\
AIDS/PGL & IgG2 anti-p55 & $36 / 70$ & 0.036 \\
AIDS/PGL & IgG3 anti-p17 & $0 / 40$ & 0.001 \\
AIDS/PGL & IgG3 anti-p24 & $0 / 15$ & 0.080 \\
AIDS/asymptomatic & IgG1 anti-p17 & $36 / 76$ & 0.003 \\
AIDS/asymptomatic & IgG1 anti-p24 & $72 / 97$ & 0.006 \\
AIDS/asymptomatic & IgG1 anti-p55 & $24 / 68$ & 0.002 \\
AIDS/asymptomatic & IgG2 anti-p17 & $36 / 78$ & 0.001 \\
AIDS/asymptomatic & IgG2 anti-p24 & $68 / 92$ & 0.021 \\
AIDS/asymptomatic & IgG2 anti-p55 & $36 / 68$ & 0.020 \\
Progressor/nonprogressor & IgG1 anti-p24 & $84 / 98$ & 0.028 \\
Progressor/nonprogressor & IgG1 anti-p55 & $36 / 67$ & 0.015 \\
Progressor/nonprogressor & IgG2 anti-p24 & $72 / 95$ & 0.007 \\
Progressor/nonprogressor & IgG2 anti-p55 & $40 / 69$ & 0.027
\end{tabular}

* Only those response frequencies that were statistically significant $(P$ $<0.05$ ) are tabulated.

${ }^{\ddagger}$ Fisher's exact test (two tailed).

frequency, or persistence of antigenic stimulation. Second, all effector functions of antibody other than antigen binding (such as complement fixation, Fc receptor binding, etc.) are determined by isotype.

The frequency of isotypic responses that we found in immunoblot (Table II) are either similar to or higher than that reported by others using whole-virus ELISA assays (33-36). Possibly some of these differences are accounted for by differences in methods or reagents. However, these assays for HIV antibody isotype were performed with whole serum. A positive reaction indicates that isotypic antibody is present and of sufficient avidity and concentration to be detected in whole serum. A negative reaction means that isotypic antibody is either not present or is present but not of sufficient avidity or concentration relative to other competing isotypes to register a positive reaction. In a sense, the assay is a functional assessment of the isotype in the context of whole serum and perhaps more biologically relevant than an assay that separates the isotype before testing for isotypic antibody. We found that the frequency of isotypic responses generally parallels the anticipated concentration of the different isotypes in serum and that the differences in frequency of isotypic responses between groups were fairly uniform and quite compatible with a general change in antibody level affecting all the isotypes. In our view, the most reasonable (and conservative) interpretation of the isotype data is that the humoral immune response to HIV has the characteristics of a mature, ongoing, T-dependent response. All isotypes can participate in the response and are affected by changes in antibody level that accompany changes in clinical status.

This study was cross-sectional in the sense that we performed laboratory studies on the men at a single point in time and longitudinal in the sense that we determined subsequent clinical outcome over a given follow-up period. As such, there were some limitations with respect to the dynamics of HIV infection that should be considered. First, we divided asymptomatic men and men with PGL into those who subsequently progressed to AIDS and compared them with men who were followed for an equal or greater period of time and did not develop AIDS. The latter group may ultimately contain men who will belong in the former group. Indeed, the distinction between progression/nonprogression may be one of relative rates of progression rather than an absolute characteristic. Nevertheless, potential misclassification of ultimate outcome decreases rather than increases the likelihood of finding significant differences between the groups. Second, if the natural history of HIV infection is such that, with time, progressive declines in CD4 cells or titer to certain viral proteins cumulatively increases the likelihood of AIDS, we may have selected men in the progressor group who have been infected longer. With the limited data available, we did not find that progressors differed from nonprogressors in duration of seropositivity $(n=21)$ or duration of lymphadenopathy $(n=38)$, nor were there correlations between these time measurements and the serologic or lymphocyte data. Finally, we do not know if the relatively lower antibody responses in progressors is an inherent feature of the response to HIV infection in these men or whether they once mounted a higher response that has declined with time. Unfortunately, too few earlier specimens from these men are available for testing to make this determination. Larger serial studies initiated at seroconversion may determine whether lower responses are markers of disease progression or determinants of progressive disease.

In the multivariate analysis, lower levels of CD4 cells were most highly associated with progression to AIDS in HIV-exposed asymptomatic men or men with PGL. Several clinical studies have shown that CD4 cell levels are lower in persons with severe clinical manifestations of HIV infection (37-39), that levels decline with increasing duration of time since exposure $(17,37$ 42), and that a low CD4 cell level is a poor prognostic sign in HIV-infected persons $(16,39-45)$. Other immunologic abnormalities can be found in HIV-infected persons, but these are usually highly correlated with CD4 cell levels $(37-39,46)$, and their association with HIV infection is not independent of their relationship to CD4 cell levels (46). Thus, clinical studies indicate that CD4 cell levels are the best immunologic marker for severity of HIV infection, a notion supported by the known tropism and cytopathic effect of HIV for CD4 cells in vitro (1).

What then is the relationship of lower levels of HIV antibody to severity of immunodeficiency, clinical status, and progression? It is known that patients with the severe immunodeficiency of AIDS mount poor primary and secondary humoral immune responses after immunization (47). If declining titers were simply a consequence of severe immunodeficiency, we would expect lowest titers in AIDS patients, low or intermediate titers in those whose condition is progressing to AIDS; and highest titers in those who are clinically and immunologically stable. We would also expect correlations between titer and severity of immunodeficiency (as measured by CD4 cell levels) when data from all subjects are pooled-regardless of their clinical status. Indeed, this is what we found. However, antibody titers to gp1 10, p24, and p51/65 were predictive of progression to AIDS independent of their association with CD4 cell levels. They were also predictive of AIDS independent of CD4 cell levels when AIDS/non-AIDS 
was the dependent variable in logistic regression analysis (data not shown). Furthermore, titers to gp1 10 were associated with progression independent of titers to p24 and p51/65. The finding of several independent associations with progression makes it unlikely that a single underlying factor is responsible. For instance, if the data we associated with progression were all surrogate markers for a single factor (such as duration of infection) which in turn was the major determinant of progression, we would not expect these "surrogates" to retain an independent association with progression when the multivariate model was adjusted for any one of them. Finally, it is difficult to explain declining titers to most proteins as a general consequence of progressive immunodeficiency when titers to gp41 remain stable and when titers to an irrelevant antigen, tetanus toxoid, do not show a similar relationship. The data indicate that the specificity and quantity of antibody are also markers for the ultimate severity of HIV infection, whether severity is measured by CD4 cell level, clinical status, or outcome.

The envelope glycoprotein gp 10 participates in binding virus to the CD4 molecule (48) and is considered a likely target for interference with virus replication by antibody $(4-6,25,29-31)$. In this context, it makes sense that lower anti-gp 10 titers might predispose to more severe CD4 cell depletion and clinical AIDS. Changes in titers to gag- and pol-encoded proteins are more difficult to explain by any postulated effect of antibody on virus infection. However, it is possible that these responses (and the gp1 10 response) are not important for their function as antigenbinding effector molecules; rather, changes in titer may be an indirect effect of some other process, immunologic or otherwise, that is important in the control of infection. The fact that HIVinfected subjects progress to AIDS despite the presence of antibody does not rule out a role for antibody, either as a direct effector or as a marker for some other immunologic process, that limits the pace at which virus replication, CD4 cell depletion, and clinical AIDS occur. The existence of such processes is supported by our data, and their dissection may contribute to improved understanding of pathogenesis and therapy.

\section{Acknowledgments}

We thank Dr. J. Curran, Dr. B. Evatt, Dr. G. Schochtmann, Dr. J. Bennett, and Dr. W. Dowdle for reviewing the manuscript, K. Foster for editorial assistance, and J. Carter for typing the manuscript.

\section{References}

1. Klatzmann, D., F. Barre-Sinoussi, M. T. Nugeyre, C. Dauguet, E. Vilmer, C. Griscelli, F. Brun-Vezinet, C. Rouzioux, J. C. Gluckman, J.-C. Chermann, and L. Montagnier. 1984. Selective tropism of lymphadenopathy associated virus (LAV) for helper-inducer $\mathrm{T}$ lymphocytes. Science (Wash. DC). 225:59-63.

2. Reinherz, E. L., and S. F. Schlossman. 1980. The differentiation and function of human T lymphocytes. Cell. 19:821-827.

3. McDougal, J. S., S. P. Cort, M. S. Kennedy, C. D. Cabradilla, P. M. Feorino, D. P. Francis, D. Hicks, V. S. Kalyanaraman, and L. S. Martin. 1985. Immunoassay for the detection and quantitation of infectious human retrovirus, lymphadenopathy-associated virus (LAV). $J$. Immunol. Methods. 76:171-183.

4. Weiss, R. A., P. R. Clapham, R. Cheingsong-Popov, A. G. Dalgleish, C. A. Carne, I. V. D. Weller, and R. S. Tedder. 1985. Neutralization of human T-lymphotropic virus type III by sera of AIDS and AIDS-risk patients. Nature (Lond.). 316:69-72.
5. Robert-Guroff, M., M. Brown, and R. C. Gallo. 1985. HTLV-IIIneutralizing antibodies in patients with AIDS and AIDS-related complex. Nature (Lond.). 316:72-74.

6. Lasky, L., J. E. Groopman, C. W. Fennie, P. M. Benz, D. J. Capon, D. J. Dowbenko, G. R. Nakamura, W. M. Nunes, M. E. Renz, and P. W. Berman. 1986. Neutralization of the AIDS retrovirus by antibodies to a recombinant envelope glycoprotein. Science (Wash. DC). 223:209212.

7. Laurence, J., F. Brun-Vezinet, S. E. Schutzer, C. Rouzioux, D. Klatzmann, F. Barre-Sinoussi, J.-C. Chermann, and L. Montagnier. 1984. Lymphadenopathy-associated viral antibody in AIDS. Immune correlations and definition of a carrier state. $N$. Engl. J. Med. 311:1269-1273.

8. Safai, B., J. E. Groopman, M. Popovic, J. Schupbach, M. G. Sarngadharan, K. Arnett, A. Sliski, and R. C. Gallo. 1984. Seroepidemiological studies of human T-lymphotropic retrovirus type III in acquired immunodeficiency syndrome. Lancet. î:1438-1440.

9. Schupbach, J., O. Haller, M. Vogt, R. Luthy, H. Joller, O. Oelz, M. Popovic, M. G. Sarngadharan, and R. C. Gallo. 1985. Antibodies to HTLV-III in Swiss patients with AIDS and pre-AIDS and in groups at risk for AIDS. N. Engl. J. Med. 312:265-770.

10. Sarngadharan, M. G., F. di Marzo Veronese, S. Lee, and R. C. Gallo. 1985. Immunological properties of HTLV-III antigens recognized by sera of patients with AIDS and AIDS-related complex and of asymptomatic carriers of HTLV-III infection. Cancer Res. 45:4574s-4577s.

11. Biggar, R. J., M. Melbye, P. Ebbesen, S. Alexander, J. O. Nielson, P. Sarin, and F. Faber. 1985. Variation in human T lymphotropic virus type III (HTLV-III) antibodies in homosexual men: decline before onset of illness related to acquired immune deficiency syndrome (AIDS). Br. Med. J. 291:997-998.

12. Kaminsky, L. S., T. McHugh, D. Stites, P. Volberding, G. Henle, W. Henle, and J. A. Levy. 1985. High prevalence of antibodies to acquired immune deficiency syndrome (AIDS)-associated retrovirus (ARV) in AIDS and related conditions but not in other disease states. Proc. Natl. Acad. Sci. USA. 82:5535-5539.

13. Groopman, J. E., F. W. Chen, J. A. Hope, J. M. Andrews, R. L. Swift, C. V. Benton, J. L. Sullivan, P. A. Volberding, D. P. Sites, S. Landesman, J. Gold, L. Baker, D. Craven, and F. S. Boches. 1986. Serologic characterization of HTLV-III infection in AIDS and related disorders. J. Infect. Dis. 153:736-742.

14. Steimer, K., J. P. Puma, M. D. Power, M. A. Powers, C. G. Nacimento, J. C. Stephans, J. A. Levy, R. Sanchez-Pescador, P. A. Luciw, P. J. Barr, and R. A. Hallewell. 1986. Differential antibody responses of individuals infected with AIDS-associated retroviruses surveyed using the viral core antigen p25 gag expressed in bacteria. Virology. 150:283290.

15. Lange, J. M. A., R. A. Coutinho, W. J. A. Krone, L. F. Verdonck, S. A. Danner, J. Van der Noordaa, and J. Goudsmit. 1986. Distinct IgG recognition patterns during progression of subclinical and clinical infection with lymphadenopathy associated virus/human $\mathrm{T}$ lymphotropic virus. Br. Med. J. 292:228-230.

16. Fishbein, D. B., J. E. Kaplan, T. J. Spira, B. Miller, L. B. Schonberger, P. F. Pinsky, J. P. Getchell, V. S. Kalyanaraman, and J. S. Braude. 1985. Unexplained lymphadenopathy in homosexual men: a longitudinal study. JAMA (J. Am. Med. Assoc.). 254:930-935.

17. Jaffe, H. W., P. M. Feorino, W. W. Darrow, P. M. O'Malley, J. P. Getchell, D. T. Warfield, B. M. Jones, D. F. Echenberg, D. P. Francis, and J. W. Curran. 1985. Persistent infection with HTLV-III/ LAV in apparently healthy homosexual men. Ann. Intern. Med. 102: 627-628.

18. Centers for Disease Control. 1985. Revision of the case definition of acquired immunodeficiency syndrome for national reporting: United States. Morbidity and Mortality Weekly Report. 34:373-375.

19. Tsang, V. C. W., J. M. Peralta, and A. R. Simons. 1983. Enzymelinked immuno-electrotransfer blot techniques (EITB) for studying the specificities of antigens and antibodies separated by gel electrophoresis. Methods Enzymol. 92:377-391.

20. Reimer, C. B., D. J. Phillips, C. H. Aloisio, D. D. Moore, G. G. 
Galland, T. W. Wells, C. M. Black, and J. S. McDougal. 1984. Evaluation of thirty-one mouse monoclonal antibodies to human IgG epitopes. $\mathrm{Hy}$ bridoma. 3:263-275.

21. Jefferis, R., C. B. Reimer, F. Skvaril, G. deLange, N. R. Ling, J. Lowe, M. R. Walker, D. J. Phillips, C. H. Aloisio, T. W. Wells, J. P. Vaerman, C. G. Magnusson, H. Kubagawa, M. Cooper, F. Vartdal, B. Vandvik, J. J. Haaijman, O. Makela, A. Sarnesto, Z. Lando, J. Gergely, E. Rajnavolgyi, G. Lazlo, J. Radl, and G. A. Molinaro. 1985. Evaluation of monoclonal antibodies having specificity for human IgG subclasses: results of an IUIS/WHO collaborative study. Immunol. Lett. 10:223252.

22. Nicholson, J. K. A., J. S. McDougal, T. J. Spira, G. D. Cross, B. M. Jones, and E. L. Reinherz. 1984. Immunoregulatory subsets of the $T$ helper and $T$ suppressor cell populations in homosexual men with chronic unexplained lymphadenopathy. J. Clin. Invest. 73:191-201.

23. Dixon, W. J. 1983. BMDP Statistical Software Manual. University of California Press, Berkeley, CA. 733 pp.

24. Schupbach, J., M. Popovic, R. V. Gilden, M. A. Gonda, M. G. Sarngadharan, and R. C. Gallo. 1984. Serologic analysis of a subgroup of human T-lymphotropic retroviruses (HTLV-III) associated with AIDS. Science (Wash. DC). 224:503-505.

25. Robey, W. G., B. Safai, S. Oroszlan, L. O. Arthur, M. A. Gonda, R. C. Gallo, and P. J. Fischinger. 1985. Characterization of envelope and core structural gene products of HTLV-III with sera from AIDS patients. Science (Wash. DC). 228:593-595.

26. DiMarzo Veronese, F., A. L. DeVico, T. D. Copeland, S. Oroszlan, R. C. Gallo, and M. G. Sarngadharan. 1985. Characterization of gp41 as the transmembrane protein coded by the HTLV-III/LAV envelope gene. Science (Wash. DC). 229:1402-1405.

27. DiMarzo Veronese, F., T. D. Copeland, A. L. DeVico, R. Rahman, S. Oroszlan, R. C. Gallo, and M. G. Sarngadharan. 1985. Characterization of highly immunogenic $\mathrm{p} 66 / \mathrm{p} 51$ as the reverse transcriptase of HTLV-III/LAV. Science (Wash. DC). 231:1289-1291.

28. Steimer, K. S., K. W. Higgens, M. A. Powers, J. C. Stephans, A Gyenes, C. George-Nascimento, P. A. Luciw, P. J. Barr, and R. A. Hallewell. 1986. Recombinant polypeptide from the endonuclease region of the acquired immune deficiency syndrome retrovirus polymerase ( $p o l)$ gene detects serum antibodies in most infected individuals. J. Virol. 58: 9-16.

29. Allan, J. S., J. E. Coligan, F. Barin, M. F. McLane, J. G. Sodroski, C. A. Rosen, W. A. Haseltine, T. H. Lee, and M. Essex. 1985. Major glycoprotein antigens that induce antibodies in AIDS patients are encoded by HTLV-III. Science (Wash. DC). 228:1091-1094.

30. Montagnier, L., F. Clavel, B. Krust, S. Chamaret, F. Rey, F. Barre-Sinoussi, and J.-C. Chermann. 1985. Identification and antigenicity of the major envelope glycoprotein of lymphadenopathy-associated virus. Virology. 144:283-289.

31. Barin, F., M. F. McLane, J. S. Allan, T. H. Lee, J. E. Groopman, and M. Essex. 1985. Virus envelope protein of HTLV-III represents major target antigen for antibodies in AIDS patients. Science (Wash. DC). 228:1094-1096.

32. Aldovini, A., C. Debouck, M. B. Feinberg, M. Rosenberg, S. K. Arya, and F. Wong-Staal. 1986. Synthesis of the complete trans-activation gene product of human T-lymphotropic virus type III in Escherichia coli: demonstration of immunogenicity in vivo and expression in vitro. Proc. Natl. Acad. Sci. USA. 83:6672-6676.

33. Aiuti, F., P. Rossi, M. C. Sirianni, M. Carbonari, M. Popovic, M. G. Sarngadharan, L. Conta, M. Moroni, S. Romgnani, and R. C. Gallo. 1985. IgM and IgG antibodies to human T cell lymphotropic retrovirus (HTLV-III) in lymphadenopathy syndrome and subjects at risk for AIDS in Italy. Br. Med. J. 291:165-166.
34. Sundqvist, V.-A., R. Linde, R. Kurth, A. Werner, E. B. Helm, M. Popovic, R. C. Gallo, and B. Wahren. 1986. Restricted IgG subclass responses to HTLV-III/LAV and to cytomegalovirus in patients with AIDS and lymphadenopathy syndrome. J. Infect. Dis. 153:970-973.

35. Bedarida, G., G. Cambie, F. D'Agostino, M. G. Ronsivalle, E. Berto, and M. E. Grisi. 1986. HIV IgM antibodies in risk groups who are seronegative on ELISA testing. Lancet. ii:570-571.

36. Parry, J. V., and P. P. Mortimer. 1986. Place of IgM antibody testing in HIV serology. Lancet. ii:979-980.

37. Schroff, R. W., M. S. Gottlieb, H. E. Prince, L. L. Chai, and J. L. Fahey. 1983. Immunological studies of homosexual men with immunodeficiency and Kaposi's sarcoma. Clin. Immunol. Immunopathol. 27:300-314.

38. Ammann, A. J., D. Abrams, M. Conant, D. Chudwin, M. Cowan, P. Volberding, B. Lewis, and C. Casavant. 1983. Acquired immune dysfunction in homosexual men: immunologic profiles. Clin. Immunol. Immunopathol. 27:315-325.

39. Lane, H. C., H. Masur, E. P. Gelmann, D. L. Longo, R. G. Steiss, T. Chused, G. Whalen, L. Edgar, and A. S. Fauci. 1985. Correlation between immunologic function and clinical subpopulations of patients with the acquired immune deficiency syndrome. Am. J. Med. 78:417422.

40. Eyster, M. E., J. J. Goedert, M. G. Sarngadharan, S. H. Weiss, R. C. Gallo, and W. A. Blattner. 1985. Development and early natural history of HTLV-III antibodies in persons with hemophilia. JAMA (J. Am. Med. Assoc.). 253:2219-2223.

41. Schwartz, K., B. R. Visscher, R. Detels, J. Taylor, P. Nishanian, and J. L. Fahey. 1985. Immunological changes in lymphadenopathy virus positive and negative symptomless male homosexuals: two years of observation. Lancet. ii:831-832.

42. Melbye, M., R. J. Biggar, P. Ebbesen, C. Neuland, J. J. Goedert, V. Faber, I. Lovenzen, P. Skinhoj, R. C. Gallo, and W. A. Blattner. 1986. Long-term seropositivity for human T-lymphotropic virus type III in homosexual men without the acquired immunodeficiency syndrome: development of immunologic and clinical abnormalities. Ann. Intern. Med. 104:496-500.

43. Metroka, C. E., S. Cunningham-Rundles, M. S. Pollack, J. A. Sonnabend, J. M. Davis, B. Gordon, R. D. Fernandez, and J. Mouradian. 1983. Generalized lymphadenopathy in homosexual men. Ann. Intern. Med. 99:585-591.

44. Goedert, J. J., M. G. Sarngadharan, R. J. Biggar, S. H. Weiss, D. Winn, R. J. Grossman, M. H. Greene, A. Bodner, D. L. Mann, D. M. Strong, R. C. Gallo, and W. A. Blattner. 1984. Determinants of retrovirus (HTLV-III) antibody and immunodeficiency conditions in homosexual men. Lancet. ii:711-716.

45. Mathur-Wagh, W., R. E. Enlow, I. Spigland, R. J. Winchester, H. S. Sacks, E. Rorat, S. R. Yancovitz, M. J. Klein, D. C. William, and D. Mildvan. 1984. Longitudinal study of persistent generalized lymphadenopathy in homosexual men: relation to AIDS. Lancet. i:1033-1037.

46. Nicholson, J. K. A., J. S. McDougal, H. W. Jaffe, T. J. Spira, M. S. Kennedy, B. M. Jones, W. W. Darrow, M. Morgan, and M. Hubbard. 1985. Exposure to human T-lymphotropic virus type III/lymphadenopathy associated virus and immunologic abnormalities in asymptomatic homosexual men. Ann. Intern. Med. 103:37-42.

47. Ammann, A. J., G. Schiffman, D. Abrams, P. Volberding, J. Ziegler, and M. Conant. 1984. B-cell immunodeficiency in acquired immune deficiency syndrome. JAMA (J. Am. Med. Assoc.). 251:1447-1449.

48. McDougal, J. S., M. S. Kennedy, J. M. Sligh, S. P. Cort, A. Mawle, and J. K. A. Nicholson. 1986. Binding of HTLV-III/LAV to $\mathrm{T} 4+\mathrm{T}$ cells by a complex of the $110 \mathrm{~K}$ viral protein and the $\mathrm{T} 4 \mathrm{molecule}$. Science (Wash. DC). 231:382-385. 